\title{
SARS-CoV-2 Seroprevalence Among Whole Blood Donors During First Wave of Covid-19 Pandemic in India
}

\author{
Srinivasa Rao Chunchu ${ }^{1}$ (D) Ushasree Ravula ${ }^{1}$ (D) Vikram Kumar Gente ${ }^{2}$. \\ Srinivas Bacchu ${ }^{2} \cdot$ S. Pandu Ranga Rao ${ }^{1} \cdot$ Srujaleswari Mooli $^{1}$
}

Received: 9 July 2021 / Accepted: 15 December 2021/Published online: 30 January 2022

(C) Indian Society of Hematology and Blood Transfusion 2021

\begin{abstract}
The current study aimed to estimate the seroprevalence of SARS-CoV-2 IgG (S-protein) antibodies along with neutralizing assay (RBD-domain) among the whole blood donors without any prior Covid-19 history or symptoms visiting Blood Centre at a Tertiary care institution, South India amidst the ongoing pandemic. During September 2020 to March 2021, 1034 whole blood donors were enrolled into the study and were screened for antiSARS-CoV-2 IgG antibodies using Chemiluminescence assay followed by neutralizing antibodies using surrogate neutralization ELISA. The study reported seroprevalence of $49.4 \%$, (95\% CI 46.3-52.5) among whole blood donors, with test sensitivity and specificity adjusted prevalence of $54.9 \%$ (95\% CI 51.5-58.3). Seroprevalence was similar across age groups, gender, voluntary/replacement donations, area of residence, $\mathrm{ABO}$ and $\mathrm{Rh}$ groups without any statistical significance. However higher IgG antibody
\end{abstract}

Ushasree Ravula

ushasreeravula@gmail.com

Srinivasa Rao Chunchu

srinivasarao.ch@esic.nic.in

Vikram Kumar Gente

vikramsahu416@gmail.com

Srinivas Bacchu

srinivasbacchu@googlemail.com

S. Pandu Ranga Rao

spresicbb@gmail.com

Srujaleswari Mooli

srujaleswarimooli@gmail.com

1 Department of Transfusion Medicine, ESIC Medical College Hospital, Sanath Nagar, Hyderabad 500038, India

2 Department of Haematology, ESIC Medical College Hospital, Sanath Nagar, Hyderabad 500038, India responses were found to be elicited in the 30-45 years age group when compared with 18-29 years age group ( $p$ value 0.046). This study also analysed the mean neutralizing capacity of SARS-CoV-2 antibodies among 97 blood donors which was 71.9 (SD: +21.03 , range 15.5 to 97.3). Donor samples with SARS-CoV-2 IgG S/Co $>9.5$ had significantly higher neutralising capacity $(>68 \%)$ when compared with donor samples of $\mathrm{S} / \mathrm{Co}<9.5$ ( $p$ value 0.000). Real-time seroprevalence studies will help to know the herd immunityamong the blood donors which will assist in knowing the Covid-19 transmission dynamics, distribution of immunity levels at a particular point in time, immunity gaps, development of novel therapeutics and prioritize the vaccination programmes to high risk individuals.

Keywords Covid-19 pandemic - SARS-CoV-2 . Neutralizing antibodies $\cdot$ Blood donors $\cdot$ Seroprevalence

\section{Introduction}

World Health Organization (WHO) has declared the novel coronavirus (COVID-19) outbreak as a global pandemic on March 11, 2020 [1]. With the onset of pandemic stringent lock down measures were imposed by Government of India in the month of March 2020 and in a phased manner unlock down was done starting from June 2021, later India experienced first wave of Covid-19 between June 2020-Feb 2021 with the peak during September 2020, where the highest daily record of cases was 97,654, over 11 million affected and 1.5 lakh deaths were reported [2] (Fig. 1). The Covid-19 pandemic being a health emergency, understanding the antibody responses among the population 


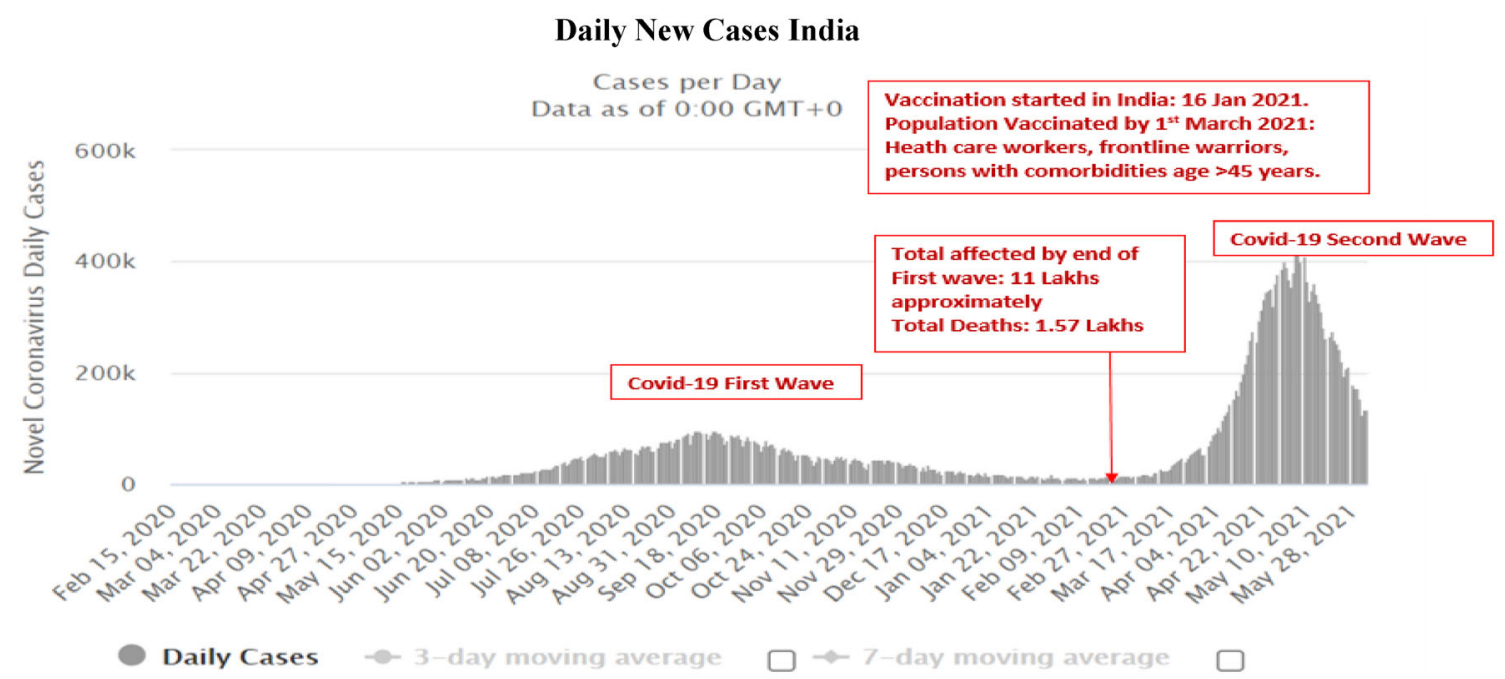

Fig. 1 Daily new Covid-19 Cases in India depicting First and Second wave.Source: https://www.worldometers.info/coronavirus/country/india/ accessed on May 31, 2021

plays a key role in decision making for effective implementation of public health measures [3].

SARS-CoV-2 seroprevalence: Seroprevalence studies reported among the general population varied widely across the globe. The accurate estimates of SARS-CoV-2 seroprevalence patterns in the general population remain essential for containment of the pandemic [4]. Population studies are a way to gain knowledge regarding the prevalence of asymptomatic and mildly symptomatic cases, to assess the potency and sustainability of the acquired immune response which is of paramount importance from a public health perspective [5]. Such individuals miss out in the classic symptom-based infection chain tracking (TestTrack-Trace), further play a role in silent spread of infection and also sustainability of the global outbreak. The seroprevalence estimates are also essential for establishing the manufacturing, delivery and deployment of vaccines on wider scale [6]. The SARS-CoV-2 antibodies against Spike proteins and RBD domain in terms of neutralizing capacity is a key correlate for the protection from Covid-19 infection. Many studies have reported antibody responses in Covid-19 using ELISA or other immunoassays, but there are limited studies using neutralizing antibody assays which are more precise.

The current study was the first to describe the seroprevalence of SARS-CoV-2 IgG antibodies (S-protein) along with neutralizing assay (RBD-domain) among the whole blood donors from India. This will contribute to the seroprevalence estimates and herd immunity among healthy, active and asymptomatic population. Real time surveillance of regular blood donors will help to monitor the waxing and waning of immunity levels over a period of time, further which guides us to understand the immune gaps and provide an opportunity to evaluate natural Covid19 transmission dynamics after each passing Covid-19 pandemic wave.

\section{Methods}

\section{Study Setting}

The prospective observational study was conducted at a Tertiary Care Centre, South India on the blood donors visiting the Blood Centre. During the study period i.e., from September 2020 to March 2021, 1034 whole blood

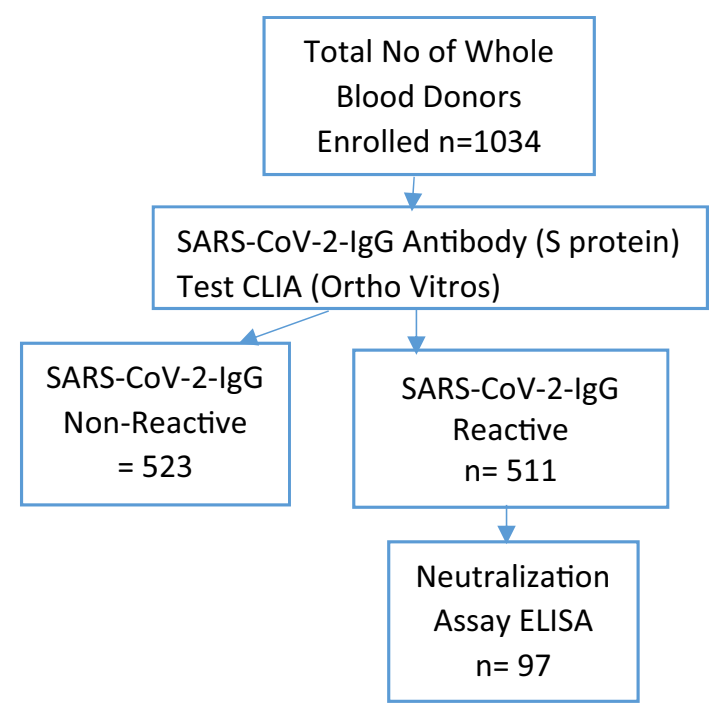

Fig. 2 Flow chart of the study 
donors who visited Blood Centre to donate blood were enrolled (Fig. 2).

\section{Subjects and Sampling}

The Blood donors who were found fit for routine whole blood donation in accordance with regulations laid by the Government of India were accepted [7, 8]. Donors not fulfilling the criteria were deferred from blood donation. All the donors enrolled were healthy and had not given any history of illness/symptoms suggestive of Covid-19 (History of cold/cough/sore throat/fever/fatigue/loss of smell or taste) in self or in the family 2 weeks prior to the donation and no history of vaccination. Subjects were defined by sociodemographic details including age (18-65 years), gender, type of donation (Voluntary/ Replacement), previous blood donation status (first time donor/repeat donor) and area of residence (Urban/ rural). No additional sampling was required except for the samples collected at the time of blood donation for mandatory tests as per our Country guidelines.

\section{Ethics Statement}

Enrolment of donors to the study was purely voluntary and non-remunerated. Samples of the whole blood donors who have provided additional written informed consent for the study were included and tested. The Institutional Ethics Committee, ESIC Medical College Hospital reviewed and approved the study protocol.

\section{Serological Testing}

The whole blood donor samples were screened for SARSCoV-2 IgG antibodies against Spike protein using a SARSCoV-2-IgG antibody kits by Chemiluminescence immunoassay (Vitros, Ortho Clinical Diagnostic, USA) as per the manufacturer's instructions. Briefly, the immunometric assay detects SARS-CoV-2 IgG antibodies bound to SARS-CoV-2 spike protein coated on the kit wells and uses horseradish peroxidase (HRP)-labelled murine monoclonal anti-human IgG antibodies as conjugate. The bound HRP conjugate is measured by luminescent reaction. Although the amount of HRP conjugate bound is indicative of amount of SARS-CoV-2 IgG antibody present, the linearity of results has not been demonstrated as per manufacturer.

Samples with Signal cutoff $(\mathrm{S} / \mathrm{Co})$ value $<1.00$ the results are interpreted as specimen sample non-reactive/ negative for SARS-CoV-2 IgG antibodies (S-Protein) and $\geq 1.00$ indicates sample is reactive / positive for antiSARS-CoV-2 IgG antibodies (S-Protein).

\section{Neutralization Assay}

SARS-CoV-2 Surrogate Virus Neutralization ELISA Test (sVNT Kit, GenScript, USA) was used to detect circulating neutralizing antibodies against SARS-CoV-2 that block/ neutralize the interaction between receptor binding domain of the viral spike glycoprotein (RBD) with ACE2 cell surface receptor. The kit is blocking ELISA detection tool which mimics the virus neutralization process. The absorbance of the sample at the end of the test is inversely dependent on the titre of anti-SARS-CoV-2 neutralizing antibodies. Test results were validated using kit positive and negative controls. Inhibition rate of the Neutralizing antibodies was calculated using the formula and expressed in percentage.

Cutoff interpretation: $\geq 30 \%$ indicates the detection of SARS-CoV-2 neutralizing antibody.

Validation and evaluation: the clinical performance of the GenScript cPass SARS-CoV-2 Neutralization Antibody detection kit was validated using the Comparator Plaque Reduction Neutralization Test (PRNT) utilizing the SARSCoV-2 virus (WA01/2020 isolate) as per manufacturer evaluation.

\section{Data Collection and Statistical Analysis}

Donor demographic details included age, gender, residential area, Type of donation (Voluntary/Replacement), donation status (first time donation/repeat donation), area of residence, history of Covid or related symptoms in self and/or family, quarantine, travel and vaccination history were retrieved from the blood centre records. Data was analyzed using Microsoft Office Version 16.0 and SPSS 22.0.

Sero-prevalence of Covid-19 antibodies was measured by crude rates, weighted prevalence, population adjusted prevalence and adjusted prevalence for test sensitivity at $96.33 \%$ and specificity at $99 \%$. Association between the sero-prevalence of anti-SARS-CoV-2 antibodies and following demographic variables- age, sex, area of residence, type of donation, donation status and Covid related history was assessed by Chi-square pearson/Fisher exact test. Correlation between variables was estimated using bivariate Pearson Correlation at $95 \%$ significance. 


\section{Results}

\section{Demographics of Study Population}

A total 1034 blood donor samples were tested, mean age of the donors was 28.8 years with age range of $18-58$ years. Majority of the study participants were males 1027 (99.3\%), $614(59.3 \%)$ were replacement donors and 420 $(40.6 \%)$ were voluntary donors. Among the study participants $414(40 \%)$ were group O donors, 297 (29\%) were group B, 247 (24\%) were group A and 76 (7\%) were group $\mathrm{AB}$, out of these 963 (93.1) were $\mathrm{Rh} \mathrm{D}$ positive and 71 (6.9\%) were $\mathrm{Rh} \mathrm{D}$ negative.

\section{Serological Test Results}

Among 1034 donor samples of whole blood donations tested, $511(49.4 \%)$ were reactive for SARS-CoV-2-IgG antibodies against $\mathrm{S}$-protein. The overall prevalence was found to be $49.4 \%$, (95\% CI 46.3-52.5) and test sensitivity and specificity adjusted prevalence was $54.9 \%$ (95\% CI 51.5-58.3). Mean antibody level (Signal Cutoff - S/Co) among the reactive cases was $5.78 \mathrm{AU} / \mathrm{mL}$ (range $1.0-16.2)$.

\section{Distribution of SARS-CoV-2 Antibody}

Seroprevalence of SARS-CoV-2 IgG (S-protein) antibody levels were distributed based on age groups, gender, type of blood donation, blood group and area of residence and analysed. No statistical significance was observed among the demographic variables (Table 1). Further, based on SARS-CoV-2 IgG antibody S/Co values were categorized as $<3.5,3.5-6,>6-12$ and $>12$ as per the guidelines issued from time to time during the pandemic where $>12$ confers to the high titers of antibodies [9]. The distribution of the demographic variables across the Antibody S/Co categories were similar with no statistical significance. However statistically significant higher immunological antibody ( $\mathrm{IgG}$ ) responses were found to be elicited by the $30-45$ years age group in comparison to the 18-29 years age group ( $p$ value 0.046) (Fig. 3).

\section{Neutralization Assay}

SARS-CoV-2 surrogate virus neutralization ELISA test was performed on 97 samples reactive for SARS-CoV-2 IgG (S-protein) antibodies with signal cut-off (S/Co) ranging from 3.06 to 16.2. The pattern of distribution of
Neutralizing capacity of SARS-CoV-2 antibodies against the SARS-CoV-2 IgG results was analysed (Fig. 4). Distribution of Neutralizing antibodies with age, gender, blood groups among the samples tested were similar and did not show any statistical significance. Donor samples with $\mathrm{S} / \mathrm{Co}>9.5$ had significantly higher neutralizing capacity $(>68 \%)$ than donor samples with $\mathrm{S} / \mathrm{Co}<9.5$ ( $p$ value 0.000 ). Also, neutralising activity was directly in correlation with SARS-CoV-2-IgG CLIA OD values (Bivariate Pearson Correlation Coefficient $p=0.000$ ).

\section{Discussion}

SARS-CoV-2 seroprevalence estimates in the community enables us to understand the total infections, including mild and asymptomatic individuals who may not get themselves tested and also guides the possible transmission interruption through depletion of susceptible individuals [6]. In a populated country like India, herd immunity threshold ( $>50 \%$ of population as per estimates) may be achieved either by natural infection or by vaccination. Until then the transmission of Covid-19 viral infection in the population is expected to occur [10]. Heterogeneity in susceptibility to infection or exposure in individuals, pre-existing immunity in the population, use of infection control, containment measures and seroprevalence estimates might alter the required threshold for herd immunity [11, 12]. Return to normalcy in social living can be achieved with adequate herd immunity.

In this study, the adjusted and weighted seroprevalence of SARS-CoV-2 IgG antibodies among 1034 whole blood donors (September 2020-February 2021) was found to be $49.4 \%$. Although the blood donors included to the study never had any history of symptomatic Covid-19 or positive diagnosis or contact history, a considerable number of blood donors i.e. 511/1034 (49.4\%) were SARS-CoV-2IgG seropositive, indicating the subclinical or asymptomatic nature of disease which missed the detection and hence containment. The asymptomatic Covid-19 infections can pose the risk of spread of infection to the vulnerable population [13]. Education of attitudes and practices among such population regarding asymptomatic infections is very essential step in containment of the spread of infection.

The main finding in this study is that, seroprevalence estimates are higher than other seroprevalence studies reported earlier to the first wave from India [6, 14-18] (Table 2, A). With phased relaxation of stringent lockdown measures after May 2020 and increased social activities, amid a backdrop of lack of adherence to covid appropriate behaviours such as wearing masks, social distancing etc. 
Table 1 Seroprevalence of SARS-CoV-2 IgG (Spike protein) antibodies and S/Co values with respect to donor demographics

\begin{tabular}{|c|c|c|c|c|c|c|c|}
\hline Variable & $\begin{array}{l}\text { Sample } \\
\text { size (n) }\end{array}$ & Reactive & $\begin{array}{l}\text { Prevalence } \\
\%\end{array}$ & $\begin{array}{l}\text { Pearson-chi } \\
\text { square value }\end{array}$ & $\begin{array}{l}\mathrm{p} \\
\text { value }\end{array}$ & $\begin{array}{l}\text { SARS-CoV-2-IgG Antibodies } \\
\text { Chemiluminescense S/CO value } \\
\text { Mean }\end{array}$ & $\begin{array}{l}\text { Sample } \\
\text { size (n) } \\
\text { (Range) }\end{array}$ \\
\hline Total & 1034 & 511 & 49.4 & - & - & 5.78 & $1.0-16.2$ \\
\hline \multicolumn{8}{|l|}{ Age group } \\
\hline $18-29$ years & 628 & 319 & 50.7 & 1.458 & 0.482 & 5.6 & $1.0-13.6$ \\
\hline 30-45 years & 377 & 177 & 46.9 & & & 6.02 & $1.03-16.2$ \\
\hline $46-65$ years & 29 & 15 & 51.7 & & & 6.68 & $1.02-13.8$ \\
\hline \multicolumn{8}{|l|}{ Gender } \\
\hline Male & 1027 & 506 & 49.2 & 1.366 & 0.243 & 5.76 & $1.1-16.2$ \\
\hline Female & 7 & 5 & 71.4 & & & 7.6 & $1.3-15.5$ \\
\hline \multicolumn{8}{|c|}{ Type of donation } \\
\hline Voluntary & 420 & 200 & 47.6 & 0.917 & 0.338 & 6.06 & $1.1-16.2$ \\
\hline Replacement & 614 & 311 & 50.6 & & & 5.59 & $1.0-15.1$ \\
\hline \multicolumn{8}{|c|}{ Donation status } \\
\hline First Time & 329 & 165 & 50.1 & 0.104 & 0.748 & 6.26 & $1.0-16.2$ \\
\hline Repeat & 705 & 346 & 49 & & & 5.55 & $1.03-16.2$ \\
\hline \multicolumn{8}{|c|}{ Area of residence } \\
\hline Urban & 716 & 368 & 51.3 & 3.640 & 0.056 & 5.78 & $1.0-16.2$ \\
\hline Rural & 318 & 143 & 41.2 & & & 5.77 & $1.02-14.3$ \\
\hline \multicolumn{8}{|l|}{ Blood groups } \\
\hline A & 247 & 123 & 49.7 & 2.202 & 0.532 & 5.3 & $1.1-15.5$ \\
\hline B & 297 & 138 & 46.4 & & & 5.75 & $1.02-15.1$ \\
\hline $\mathrm{AB}$ & 76 & 42 & 56 & & & 5.69 & $1.1-13.2$ \\
\hline $\mathrm{O}$ & 414 & 208 & 50 & & & 5.75 & $1.03-16.2$ \\
\hline \multicolumn{8}{|l|}{$R h$ group } \\
\hline $\begin{array}{l}\mathrm{Rh} \mathrm{D} \\
\text { positive }\end{array}$ & 963 & 472 & 49.0 & 1.888 & 0.386 & 5.82 & $1.1-16.2$ \\
\hline $\begin{array}{l}\text { Rh D } \\
\text { negative }\end{array}$ & 71 & 39 & 54.9 & & & 5.23 & $1.2-10.6$ \\
\hline
\end{tabular}

would have led to increased exposure and hence increase in Covid-19 spread and thus seroprevalence.

Seroprevalence estimate of $49.4 \%$ reported in our study was also higher than reported estimates from various countries [19-28] (Table 2, B) The higher seroprevalence estimates in comparison to other studies may be due to various factors like geographical distribution of Covid-19 pandemic, the timing of the pandemic spread, population statistics, early initiation of containment measures and antibody testing strategies in respective countries. Also our study was done later in comparison to the other studies and thus increased seroprevalence.

The seroprevalence estimates in the study across the demographics parameters like age groups, ABO blood groups, type of blood donation, and residential area remained similar with no statistical difference $(p>0.05)$. Although age-dependent pattern of disease severity in
Covid-19 was discussed in previous studies [19, 29], overall seroprevalence among higher age group (46-65 years) was higher $(51.1 \%)$ in comparison to other age groups but statistical significance was not established due to low turn-out of donors from 46 to 65 years age group who were at high risk during first wave of Covid-19 pandemic in India (Table 1). The mean of S/Co within each cut off range was compared across the different age groups of donors and no statistical significance was found. However higher immunological antibody $(\mathrm{IgG})$ responses were found to be elicited by the 30-45 years age group in comparison to the 18-29 years age group ( $p$ value 0.046 ). More studies may be required to understand the immunological differences among blood donors belonging to different age groups and it could potentially lay the groundwork for further research in vaccine development and therapeutics. 

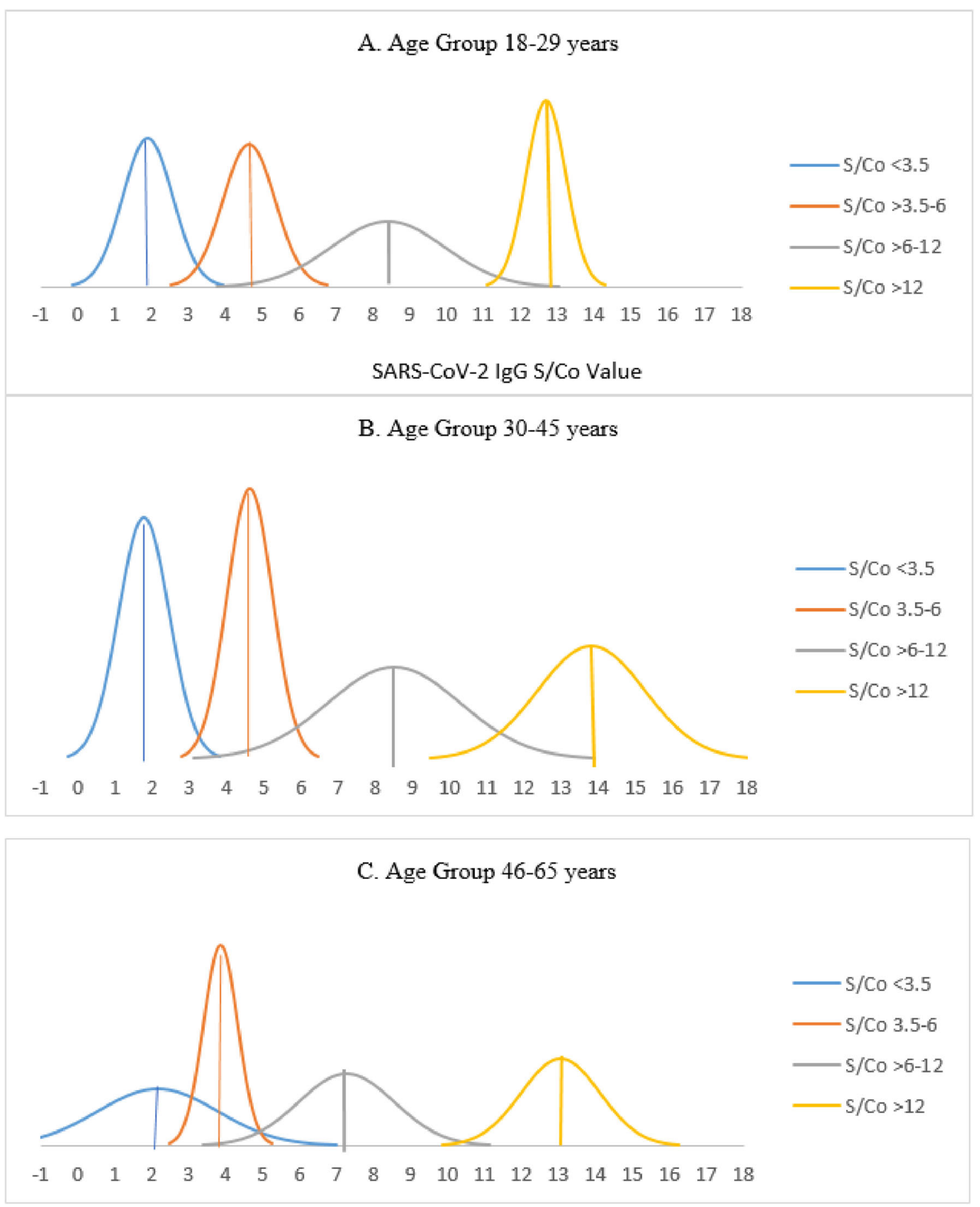

Fig. 3 Comparison of SARS-CoV-2-IgG Antibody S/Co across the age groups. Considering various guidelines for Convalescent plasma therapy $[9,38]$, the whole blood donors with SARS-CoV-2 Ig antibody positivity were categorised based on the S/Co value as $<3.5,3.5-6,>6-12$ and $>12$. The mean of S/Co $<3.5$ among the age groups $18-29$ years, 30-45 years and 46-65 years was 1.9, 1.77 and 2.16 respectively, mean among $3.5-6$ was $4.64,4.62$, 3.86; among

No significant difference in seroprevalence estimates across the $\mathrm{ABO}$ groups was observed in our study while Golinelli et al. (2020) showed association of group-A blood
$>6-12$ was $8.41,8.5,7.27$ and among $>12$ was $12.7,13.8,13.05$. The mean of S/Co within each cut off range was compared across the different age groups of donors and no statistical significance was found. However higher immunological antibody ( $\mathrm{IgG}$ ) responses were found to be elicited by the $30-45$ years age group in comparison to the 18-29 years age group ( $p$ value 0.046 )

donors with higher seroprevalence of SARS-CoV-2 antibodies [30], and Guillon et al. (2008) reported that a monoclonal anti-A antibody was able to inhibit SARS-CoV 


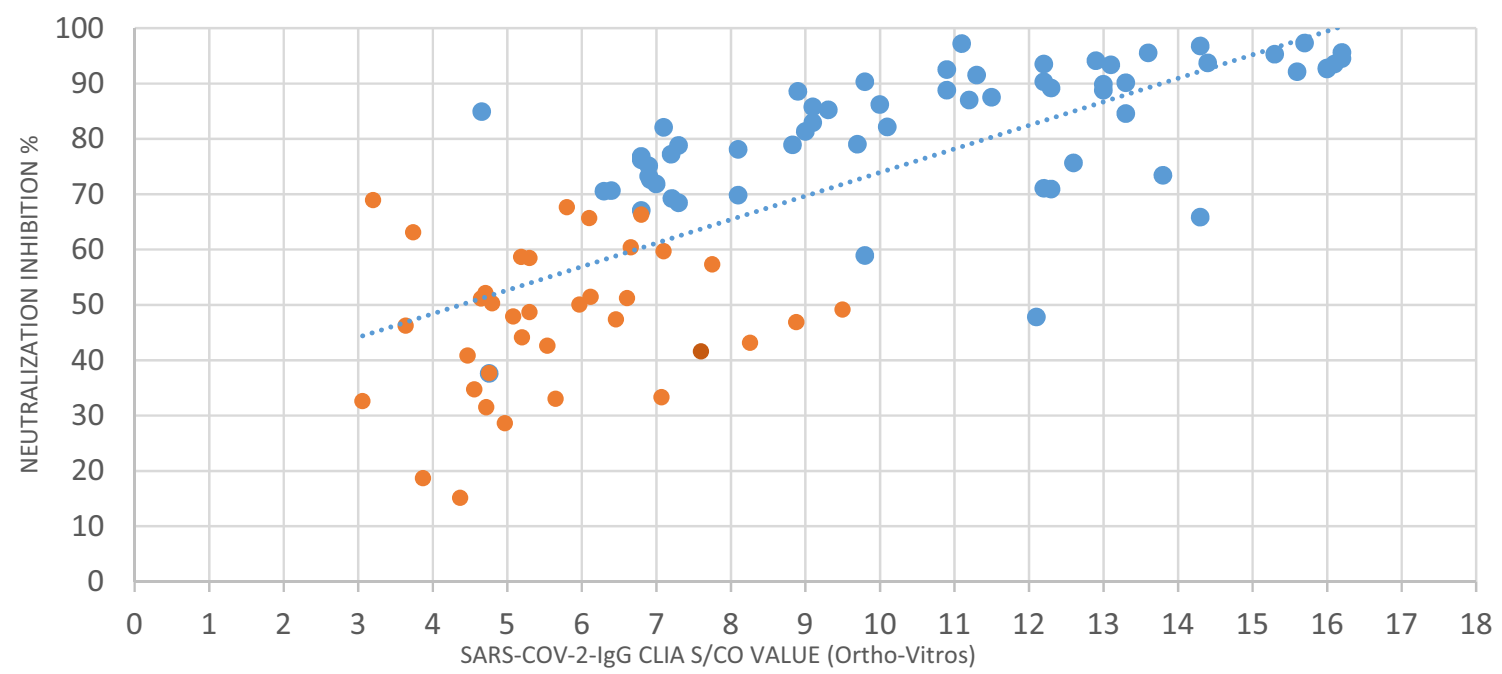

Fig. 4 Correlation analysis of SARS-CoV-2 IgG antibodies and Neutralizing Capacity (\%) among asymptomatic whole blood donors. $\mathrm{AABB}$ suggested $\mathrm{S} / \mathrm{Co} \geq 9.5$ (Ortho, Vitros) as high titre [9], considering this as cut-off, $38(39 \%)$ of donor samples with CLIA $\mathrm{S} / \mathrm{Co} \geq 9.5$ had higher mean neutralization of $85.4 \%$ (range 47.7-97.3) than $59(61 \%)$ of donors with CLIA S/Co $<9.5$

S protein/ACE2 dependent adhesion [31]. Larger sample studies may be required to estimate the $\mathrm{ABO}$ group specific seroprevalence estimates. Also, the other studies included the general population while our study included a specific set of population- i.e., blood donors.

In our study the mean neutralizing capacity of SARSCoV-2 antibodies among 97 blood donors was 71.9 $(\mathrm{SD} \pm 21.03$ range 15.5 to 97.3$)$. The distribution of neutralizing antibody capacity across age groups and $\mathrm{ABO}$ blood groups showed no significant difference. On assessing the Chemiluminescence assay S/Co and Neutralization Inhibition, linear association was observed (Fig. 4, \%). Donor samples with S/Co $>9.5$ had significantly higher neutralising capacity $(>68 \%)$ than donor samples with $\mathrm{S} / \mathrm{Co}<9.5$ ( $p$ value 0.000 ). Our study findings are complying with US FDA guidelines, considering for the high titre convalescent plasma $[9,38]$. Understanding the neutralizing antibody responses of the individuals is a key correlate to protection from reinfection, address herd immunity, vaccine efficacy studies and real time sero surveillance for future pandemic preparedness.

Plaque reduction Neutralization Test (PRNT) is gold standard in estimating the neutralizing antibody titres, due to various limitations in handling live viral cultures, surrogate-based assays are in use [32,33]. Though S/Co cutoffs from various SARS-CoV-2 antibody assays provide rough estimates of Neutralizing antibody titres, estimation of individual units for neutralizing capacity is essential in terms of Convalescent plasma therapy efficacy and outcomes [34]. (neutralization mean: 58.4\%). Donor samples with $\mathrm{S} / \mathrm{Co} \geq 9.5$ depicted as blue dots had significantly higher neutralising capacity $(\geq 68 \%$ ) than donor samples with S/Co $<9.5$ - orange dots ( $p$ value $0.000)$. Neutralising activity was directly in correlation with SARSCoV-2-IgG CLIA OD values (Bivariate Pearson Correlation Coefficient $p=0.000)$ (colour figure online)

As pandemic progresses further, and with new variant/mutant SARS-CoV-2 emerging the real time surveillance of SARS-CoV-2 antibodies among the population as well as blood donors helps in estimating the disease burden, herd immunity and to strategize vaccination for at risk individuals [35]. Immunity gaps identified through multiple data sources, including serology, can be used to target specific interventions and improve routine programs to prevent future gaps.

Donors who recover from recent/ variant induced Covid-19 infections are likely to generate high titre antibodies capable of neutralizing variants [36]. Hence the variant Convalescent plasma could be a potential antidote for variant strains of SARS-CoV-2 [37, 38]. Further, high titre whole blood derived convalescent plasma may be utilised for Convalescent Plasma Therapy [39-42] in nonresponders to Covid-19 vaccines, preparing hyperimmunoglobulins [43], monoclonal antibodies and lyophilized products [44].

The limitations of our study were: we included participants who are blood donors in the age group 18-65 years, hence the obtained seroprevalence may not be representative of the general population. And asymptomatic donors were included, thus the seroprevalence may vary over time due to waning of antibody levels, and may underestimate the actual proportion of the population who might have been previously infected with SARS-CoV-2. 
Table 2 SARS-CoV-2 Seroprevalence studies

\begin{tabular}{|c|c|c|c|c|}
\hline $\begin{array}{l}\text { Country/State, } \\
\text { Author }\end{array}$ & Period & Method & Study population & Seroprevalence \\
\hline \multicolumn{5}{|c|}{ A. Seroprevalence Studies from India } \\
\hline $\begin{array}{l}\text { Delhi } \\
\text { Pandey H. C. }\end{array}$ & April-July 2020 & SARS-CoV-2 IgG (Abbott) & 1191 blood donors & $9.5 \%$ \\
\hline Karnataka & June 2020 & SARS-CoV-2 IgG & 509 adults & $8.5 \%(95 \%$ CI $6.9-10.8 \%)$ \\
\hline $\begin{array}{l}\text { Inbaraj L. R. } \\
\text { et al. (2020) }\end{array}$ & & ECLIA & & \\
\hline $\begin{array}{l}\text { Delhi } \\
\text { Gupta et al. } \\
\text { (2021) }\end{array}$ & June-July 2020 & $\begin{array}{l}\text { Anti SARS-CoV-2 Total } \\
\text { CLIA }\end{array}$ & $\begin{array}{l}3939 \text { health care } \\
\text { workers }\end{array}$ & $13 \%$ \\
\hline $\begin{array}{l}\text { Karnataka } \\
\text { Mohanan M. } \\
\text { et al. (2020) }\end{array}$ & June-August 2020 & $\begin{array}{l}\text { SARS-CoV-2 IgG } \\
\text { ELISA }\end{array}$ & $\begin{array}{l}2912 \text { household } \\
\text { population }\end{array}$ & $37.4-45.6 \%$ \\
\hline $\begin{array}{l}\text { India } \\
\text { Murhekar V. } \\
\text { et al }\end{array}$ & $\begin{array}{l}\text { August- } \\
\text { September } 2020\end{array}$ & Anti-SARS-CoV-2-IgG (Abbott) & 29,082 households & $10.8 \%$ \\
\hline $\begin{array}{l}12 \text { cities India } \\
\text { Velumani A. } \\
\text { et al. (2021) }\end{array}$ & $\begin{array}{l}\text { July-December } \\
2020\end{array}$ & $\begin{array}{l}\text { SARS-CoV-2 IgG } \\
\text { CLIA }\end{array}$ & $\begin{array}{l}\text { 4,48,518 self-referred } \\
\text { individuals }\end{array}$ & $31 \%$ \\
\hline Current Study & $\begin{array}{l}\text { September 2020- } \\
\text { March } 2021\end{array}$ & $\begin{array}{l}\text { SARS-CoV-2 IgG CLIA (spike } \\
\text { protein) }\end{array}$ & $\begin{array}{l}1034 \text { asymptomatic } \\
\text { Blood Donors }\end{array}$ & $49.4 \%(95 \%$ CI $46.3-52.5)$ \\
\hline \multicolumn{5}{|c|}{ B. Seroprevalence Studies across the World } \\
\hline $\begin{array}{l}\text { France } \\
\text { Gallian et al. } \\
(2020)\end{array}$ & March-April 2020 & Antibodies Neutralizing SARS-CoV-2 & 998 blood donors & $2.7(\mathrm{n}=27)$ \\
\hline $\begin{array}{l}\text { Denmark } \\
\text { Erikstrup et al. } \\
\text { (2020) }\end{array}$ & $\begin{array}{l}\text { April 6-May } 9 \\
2020\end{array}$ & $\begin{array}{l}\text { Commercial Lateral Flow test for IgG/ } \\
\text { IgM }\end{array}$ & 20,640 Blood Donors & $1.9 \%(95 \%$ CI $0.8-2.3 \%)$ \\
\hline $\begin{array}{l}\text { Geneva } \\
\text { Stringhini et al. } \\
\text { (2020) }\end{array}$ & April-May 2020 & Anti-SARS-CoV-2-IgG ELISA & $\begin{array}{l}2766 \text { household } \\
\text { participants }\end{array}$ & $\begin{array}{l}4.8 \%(95 \% \text { CI } 2.4-8.05 \%) \text { to } 10.8 \% \\
\quad(95 \% \text { CI } 8.2-13.9 \%)\end{array}$ \\
\hline $\begin{array}{l}\text { Spain } \\
\text { Pollan M. (2020) }\end{array}$ & April-May 2020 & $\begin{array}{l}\text { SARS-CoV-2 IgG (nucleoprotein) } \\
\text { Abbott }\end{array}$ & $\begin{array}{l}61,075 \text { household } \\
\text { participants }\end{array}$ & $5 \%(95 \%$ CI 4.7-5.4) \\
\hline $\begin{array}{l}\text { Kenya } \\
\text { Uyoga S. et al. } \\
(2021)\end{array}$ & April-June 2020 & SARS-CoV-2 IgG ELISA & 3098 blood donors & $5.6 \%(95 \%$ CI $4.8-6.5 \%)$ \\
\hline $\begin{array}{l}\text { Saudi Arabia } \\
\text { Mahallawi H. } \\
\text { et al. (2020) }\end{array}$ & May-July 2020 & SARS-CoV-2 IgG ELISA & $\begin{array}{l}1212 \text { Asymptomatic } \\
\text { Blood Donors }\end{array}$ & $19.31 \%(95 \%$ CI $17.1-21.6 \%)$ \\
\hline $\begin{array}{l}\text { Pakistan } \\
\text { Younas A. et al }\end{array}$ & June-July 2020 & ECLIA, ELISA (IgG, IgM) & $\begin{array}{l}380 \text { healthy blood } \\
\text { donors }\end{array}$ & $33.6 \%$ \\
\hline $\begin{array}{l}\text { Romania } \\
\text { Tudor Rares } \\
\text { et al. }(2021)\end{array}$ & $\begin{array}{l}\text { July-September } \\
2020\end{array}$ & $\begin{array}{l}\text { Anti SARS-CoV-2 Total (IgA, IgM, } \\
\text { IgG) antibodies ECLIA }\end{array}$ & 2115 blood donors & $1.51 \%(95 \%$ CI $1.07-2.13 \%)$ \\
\hline Current Study & $\begin{array}{l}\text { September 2020- } \\
\text { March } 2021\end{array}$ & $\begin{array}{l}\text { SARS-CoV-2 IgG CLIA (spike } \\
\text { protein) }\end{array}$ & $\begin{array}{l}1034 \text { asymptomatic } \\
\text { Blood Donors }\end{array}$ & $49.4 \%(95 \%$ CI $46.3-52.5$ \\
\hline
\end{tabular}




\section{Conclusion}

The prevalence of SARS-CoV-2 IgG antibodies among the asymptomatic blood donors was high and no significant difference was observed across age groups or $\mathrm{ABO} / \mathrm{Rh}$ blood type. Neutralizing antibody assays will help to understand the immune responses to SARS-CoV-2 among healthy asymptomatic regular blood donors over a period of time. Further, identifying the seropositive blood units will help to monitor any benefits or serious adverse events to the recipients arising due to transfusion of such blood or blood components.

Real-time seroprevalence studies will help to know the herd immunity among the blood donors which will assist in knowing the Covid-19 transmission dynamics, distribution of immunity levels at a particular point in time, immunity gaps, development of novel therapeutics and prioritize the vaccination programmes to high risk individuals.

Acknowledgements The authors would like to thank all the Blood donors for their participation to the study. We would especially thank Prof. Srinivas M (Dean of the Institute), Blood Centre staff and Ethics Committee. The funders were not involved in the study.

\section{Declarations}

Conflict of interest The authors declare no conflict of interest.

\section{References}

1. World Health Organization Media briefing. https://www.who.int/ director-general/speeches/detail/who-director-general-s-openingremarks-at-the-media-briefing-on-covid-19-11-march-2020

2. Worldometer. Coronavirus: India, World. https://www.world ometers.info/coronavirus/\#countries. Accessed 31 May 2021

3. Aziz NA, Corman VM, Echterhoff AKC, Müller MA, Richter A, Schmandke A, Schmidt ML, Schmidt TH, de Vries FM, Drosten C, Breteler MMB (2021) Seroprevalence and correlates of SARSCoV-2 neutralizing antibodies from a population-based study in Bonn, Germany. Nat Commun 12(1):2117. https://doi.org/10. 1038/s41467-021-22351-5.PMID:33837204;PMCID:PMC80351 81

4. Ibarrondo FJ et al (2020) Rapid decay of anti SARS-CoV-2 antibodies in persons with mild Covid-19. N Engl J Med 383(11):1085-1087

5. Winter K, Martinez ME et al (2018) Benefits and challenges in using seroprevalence data to inform models for measles and Rubella elimination. J Infect Dis 218(3):355-364

6. Murhekar MV, Bhatnagar T, Selvaraju S, Saravanakumar V, Thangaraj JWV et al (2021) ICMR Serosurveillance Group. SARS-CoV-2 antibody seroprevalence in India, AugustSeptember, 2020: findings from the second nationwide household serosurvey. Lancet Glob Health 9(3):e257-e266. https://doi.org/ 10.1016/S2214-109X(20)30544-1. Epub 2021 Jan 27. PMID: 33515512; PMCID: PMC7906675

7. Drugs and Cosmetics Act 1940 and Rules 1945, Ministry of Health and Family welfare, Government of Inida. Amended. https://cdsco.gov.in/opencms/export/sites/CDSCO_WEB/Pdf-
documents/acts_rules/2016DrugsandCosmeticsAct1940Rules 1945.pdf

8. Guidelines for Blood Donor selection and Blood Donor Referral. National Blood Transfusion Council. http://nbtc.naco.gov.in/ assets/resources/policy/Letter-reg-\%20guidelines-for-blooddonor-selection\&referral-2017.pdf

9. Toolkit Updated 04/14/21 COVID-19 Convalescent Plasma (CCP) Under Emergency Use Authorization. American Association of Blood Banking (AABB). https://www.aabb.org/docs/ default-source/default-document-library/regulatory/toolkit-for-ccpunder-eua.pdf?sfvrsn=741be857_18

10. Britton T, Ball F, Trapman P (2020) A mathematical model reveals the influence of population heterogenicity on herd immunity to SARS-CoV-2. Science 369:846-849

11. Aguas R, Corder RM, King JG, Goncalves G, Ferreira MU, Gomes MG (2020) Herd immunity thresholds for SARS-CoV-2 estimated from unfolding epidemics. medRxiv

12. Simoneaux R, Shafer SL (2020) Can herd immunity save us from COVID-19? ASA Monit 84:18-19. https://doi.org/10.1097/01. ASM.0000718812.88829.39

13. Wilmes P, Zimmer J, Schulz J, Glod F, Veiber L, Mombaerts L, Rodrigues B, Aalto A, Pastore J, Snoeck CJ, Ollert M, Fagherazzi G, Mossong J, Goncalves J, Skupin A, Nehrbass U (2021) SARSCoV-2 transmission risk from asymptomatic carriers: Results from a mass screening programme in Luxembourg. Lancet Reg Health Eur 4:100056. https://doi.org/10.1016/j.lanepe.2021. 100056. Epub 2021 Feb 27. PMID: 33997830; PMCID: PMC7912359

14. Inbaraj LR, George CE, Chandrasingh S (2021) Seroprevalence of COVID-19 infection in a rural district of South India: a population-based seroepidemiological study. PLoS ONE 16(3):e0249247. https://doi.org/10.1371/journal.pone.0249247. PMID:33788873;PMCID:PMC8011723

15. Pandey HC, Dhiman Y, Chippy SC, Coshic P, Jain P (2021) Seroprevalence of SARS-Coronavirus 2 among asymptomatic healthy blood donors from healthcare and non-healthcare settings: implications for safety of blood donors and blood collection staff during blood donation. Transfus Apher Sci 60(3):103118. https://doi.org/10.1016/j.transci.2021.103118

16. Gupta R, Dwivedi T, Gajendra S, Sahoo B, Gupta SK, Vikas H, Singh AR, Mohan A, Bhatnagar S, Singh S, Wundavalli L, Guleria R (2021) Seroprevalence of antibodies to SARS-CoV-2 in healthcare workers \& implications of infection control practice in India. Indian J Med Res 153(1 \& 2):207-213. https://doi.org/ 10.4103/ijmr.IJMR_3911_20. PMID: 33642348; PMCID: PMC8184075

17. Velumani A, Nikam C, Suraweera W, Fu SH, Gelband H, Brown PE, Bogoch I, Nagelkerke N, Jha P (2021) SARS-CoV-2 Seroprevalence in 12 Cities of India from July to December 2020. medRxiv

18. Mohanan M, Malani A, Krishnan K, Acharya A (2021) Prevalence of SARS-CoV-2 in Karnataka, India. JAMA 325(10):1001-1003. https://doi.org/10.1001/jama.2021.0332

19. Olariu TR, Lighezan R, Ursoniu S et al (2021) Seroprevalence of SARS-CoV-2 antibodies in 2115 blood donors from Romania. Clin Microbiol Infect 27(5):817-819. https://doi.org/10.1016/j. cmi.2020.12.027

20. Erikstrup C, Hother CE et al (2021) Estimation of SARS-CoV-2 infection fatality rate by real-time antibody screening of blood donors. Clin Infect Dis 72(2):249-253. https://doi.org/10.1093/ $\mathrm{cid} / \mathrm{ciaa} 849$

21. Gallian P, Pastorino B, Morel P et al (2020) Lower prevalence of antibodies neutralising SARS-CoV-2 in group O French blood donors. Antiviral Res 181:104880. https://doi.org/10.1016/j.anti viral.2020.104880 
22. Uyoga S, Adetifa MO, Karanja K et al (2021) Seroprevalence of anti-SARS-CoV-2 IgG antibodies in Kenyan blood donors. Science 371(6524):79-82. https://doi.org/10.1126/science.abe1916

23. Stringhini S, Wisniak A, Piumatti G, Azman AS (2020) Seroprevalence of anti-SARS-CoV-2 IgG antibodies in Geneva, Switzerland (SEROCoV-POP): a population-based study. The Lancet 396(10247):313-319. https://doi.org/10.1016/S01406736(20)31304-0

24. Pollan M, Perez-Gomez B et al (2020) Prevalence of SARS-CoV2 in spain (ENE-COVID): A nation-wide, population based seroepidemiological study. The Lancet 396(10250):535-544

25. Vena A, Berruti M, Adessi A, Blumetti P, Brignole $M$ et al (2020) Prevalence of antibodies to SARS-CoV-2 in Italian adults and associated risk factors. J Clin Med 9:E2780

26. McLaughlin CC, Doll MK, Morrison KT, McLaughlin WL, O'Connor T, Sholukh AM, Bossard EL, Phasouk K, Ford ES, Diem K, Klock AM, Jerome KR, Corey L (2020) High community SARS-CoV-2 antibody seroprevalence in a Ski Resort Community, Blaine County, Idaho, US. Preliminary results. medRxiv [Preprint]. 2020 Jul 21:2020.07.19.20157198. https:// doi.org/10.1101/2020.07.19.20157198. PMID: 32743610; PMCID: PMC7386534.

27. Naranbhai V, Chang CC, Beltran WFG, Miller TE, Astudillo MG, Villalba JA, Yang D, Gelfand J, Bernstein BE, Feldman J, Hauser BM, Caradonna TM, Alter G, Murali MR, Jasrasaria R, Quinlan J, Xerras DC, Betancourt JR, Louis DN, Schmidt AG, Lennerz J, Poznansky MC, Iafrate AJ (2020) High seroprevalence of anti-SARS-CoV-2 antibodies in Chelsea, Massachusetts. J Infect Dis 222(12):1955-1959. https://doi.org/10.1093/infdis/ jiaa579.PMID:32906151;PMCID:PMC7499676

28. Younas A, Waheed S, Khawaja S, Imam M, Borhany M, Shamsi $\mathrm{T}$ (2020) Seroprevalence of SARS-CoV-2 antibodies among healthy blood donors in Karachi, Pakistan. Transfus Apher Sci 59(6):102923. https://doi.org/10.1016/j.transci.2020.102923

29. Davies NG, Klepac P, Liu Y et al (2020) Age-dependent effects in the transmission and control of COVID-19 epidemics. Nat Med 26:1205-1211. https://doi.org/10.1038/s41591-020-0962-9

30. Golinelli D, Boetto E, Maietti E, Fantini MP (2020) The association between $\mathrm{ABO}$ blood group and SARS-CoV-2 infection: a meta-analysis. PLoS ONE 15(9):e0239508. https://doi.org/10. 1371/journal.pone.0239508

31. Guillon P, Clément M, Sébille V, Rivain J-G et al (2008) Inhibition of the interaction between the SARS-CoV Spike protein and its cellular receptor by anti-histo-blood group antibodies. Glycobiology 18(12):1085-1093. https://doi.org/10.1093/glycob/ cwn093

32. Garcia-Beltran WF, Lam EC et al (2021) COVID-19-neutralizing antibodies predict disease severity and survival. Cell 184(2):476-488. https://doi.org/10.1016/j.cell.2020.12.015

33. Muruato AE, Fontes-Garfias CR, Ren P et al (2020) A highthroughput neutralizing antibody assay for COVID-19 diagnosis and vaccine evaluation. Preprint. bioRxiv. 2020.05.21.109546. Published 2020 May 22. https://doi.org/10.1101/2020.05.21. 109546
34. Wong SS, Yuen KY (2008) The management of coronavirus infections with particular reference to SARS. J AntimicrobChemother 62:437-441

35. Lai C-C, Wang J-H, Hsueh P-R (2020) Population-based seroprevalence surveys of anti-SARS-CoV-2 antibody: an up-to-date review. Int J Infect Dis 101:314-322. https://doi.org/10.1016/j. ijid.2020.10.011

36. Körper S, Jahrsdörfer B, Corman VM, Pilch J, Wuchter P, Blasczyk R, Müller R, Tonn T, Bakchoul T, Schäfer R, Juhl D, Schwarz T, Gödecke N, Burkhardt T, Schmidt M, Appl T, Eichler H, Klüter H, Drosten C, Seifried E, Schrezenmeier H (2021) Donors for SARS-CoV-2 convalescent plasma for a controlled clinical trial: donor characteristics, content and time course of SARS-CoV-2 neutralizing antibodies. Transfus Med Hemother 48:137-147. https://doi.org/10.1159/000515610

37. Casadevall A, Henderson JP, Joyner MJ, Pirofski LA (2021) SARS-CoV-2 variants and convalescent plasma: reality, fallacies, and opportunities. J Clin Investig 131(7)

38. Bendezú Palacio A, Parejas Sosa C, Chunga Tume P (2021) Una nueva alternativa: terapia con plasma de convalecientes, posible antídoto en tiempos de COVID-19 [A new alternative: convalescent plasma therapy, possible antidote in times of COVID-19]. Medicina (B Aires) 81(2):307. Spanish. PMID: 33906157

39. Ravula U, Chunchu SR, Gente VK (2021) Whole blood derived covid convalescent plasma: an economical option among developing countries. Transfus Apher Sci 60(2):103045. https://doi. org/10.1016/j.transci.2020.103045. Epub 2021 Jan 2. PMID: 33419658; PMCID: PMC7776123.

40. Mandal A, Chakrabarty R, Datta SS (2021) Whole blood derived covid convalescent plasma: a practical experience from India. Transf Apher Sci

41. US Food \& Drugs Admnistration (2021) Investigational Covid-19 Convalescent Plasma. Guidance for Industry. https://www.fda. gov/regulatory-information/search-fda-guidance-documents/ investigational-covid-19-conmvalescent-plasma

42. Cunningham AC, Goh HP, Koh D (2020) Treatment of Covid-19: old tricks for new challenges. Crit Care 24:91

43. Piechotta V, Chai KL, Valk SJ, Doree C, Monsef I, Wood EM, Lamikanra A, Kimber C, McQuilten Z, So-Osman C, Estcourt LJ, Skoetz N (2020) Convalescent plasma or hyperimmune immunoglobulin for people with COVID-19: a living systematic review. Cochrane Database Syst Rev 7(7):CD013600. https://doi. org/10.1002/14651858.CD013600.pub2. Update in: Cochrane Database Syst Rev. 2020 Oct 12;10:CD013600. PMID: 32648959; PMCID: PMC7389743

44. Ngamcherdtrakul W, Sangvanich T, Reda M, Gu S, Bejan D, Yantasee W (2018) Lyophilization and stability of antibodyconjugated mesoporous silica nanoparticle with cationic polymer and PEG for siRNA delivery. Int J Nanomed 10(13):4015-4027. https://doi.org/10.2147/IJN.S164393.PMID:30022824;PMCID: PMC6045907

Publisher's Note Springer Nature remains neutral with regard to jurisdictional claims in published maps and institutional affiliations. 